\title{
THE DISTRIBUTION OF FLOOD HYDROGRAPH RECESSION CONSTANT FOR CHARACTERIZATION OF KARST SPRING AND UNDERGROUND RIVER FLOW COMPONENTS RELEASING WITHIN GUNUNG SEWU KARST REGION
}

\author{
Tjahyo Nugroho Adji and M.Misqi \\ Department of Environmental Geography, Gadjah Mada University, Yogyakarta, Indonesia \\ Email: adji@geo.ugm.ac.id ; mm.salafy@gmail.com
}

\begin{abstract}
This research is carried out within two caves with underground river and one karst spring, which is located in Gunung Sewu karst area, Gunung Kidul. The objective of this research is to recognize some flood hydrograph properties of karst aquifer characterization in order to compare the comportment of aquifer to release its flow components between underground river and karst spring. Water level data loggers are installed within two caves and one karst spring represent upper, middle, and lower elevation of karst topography, which are Beton, Seropan, and Toto Cave, respectively. In addition, time series discharge measurement in correspond to minimum, average, and maximum flow events is conducted to formulate the Annual Stage Discharge Rating Curve. Thereby, the full year river hydrograph may be defined. Afterwards, by selecting several flood hydrograph events, the recession constant in each cave including diffuse flow $\left(\mathrm{K}_{\mathrm{b}}\right)$, fissure flow $\left(\mathrm{K}_{\mathrm{i}}\right)$, and conduit flow $\left(\mathrm{K}_{\mathrm{c}}\right)$ recession constant, is then calculated and compared in every location. The result shows that Beton Spring that represents the upper part of research area confirms the quickest respond towards rainfall events. Also, this point specifies the medium number of diffuse recession constant $\left(\mathrm{K}_{\mathrm{b}}=0.983\right)$, compared to Seropan (0.996), and Toto (0.937), means that the aquifer surrounding Toto Cave release its groundwater storage faster than Beton Spring and Seropan Cave. On the contrary, Seropan Cave performs the highest value of diffuse recession constant (0.996) and this situation is confirmed by its dry season discharge that still above 810 lt/second.
\end{abstract}

\section{INTRODUCTION}

Characterization of karst aquifer is considered by most hydrologists complicated because of its heterogeneous and anisotropic condition (Ford and Williams, 1992). By Blair (2004), this is even considered as a character in a unique compared to other types of aquifers, due to strong 
control of the geological structure. The structure is meant here is because of the nature and effect of the deformation of the bedrock material. Limestone near the surface of the soil has a tendency toward the occurrence of cracks, and because of the dissolution process of further rain water later formed cracks in different directions (joint), which does not irregular or what is known as a conduit or secondary porosity (Gillieson, 1996; Adji, 2005). Figure 1 further shows the difference between the porosity of the karst aquifer and non-karstic aquifer.

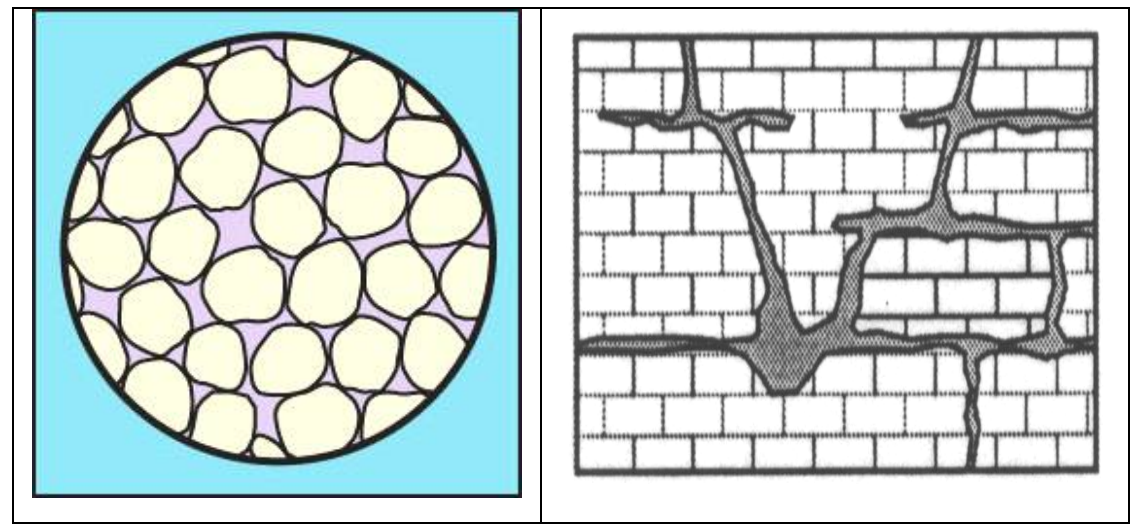

Figure 1. Porosity differences in non-karst aquifer and isotropic (left), and anisotropic in the karst aquifer (Haryono and Adji, 2004))

Furthermore, White (1988), Ford and Williams (1992), Smart and Hobbes (1986), and Gillieson (1996), in principle divide the flow characteristics in karst aquifer into three components, namely: conduit flow), fissure flow, diffuse flow. Meanwhile, by Domenico and Schwarts (1990), the component flow in the karst aquifer that is only divided into two parts, diffuse flow and conduit flow, as shown in Figure 2. Diffuse flow component is recharged by the infiltration of water stored in the karst hills (Haryono, 2001) and fills karst underground rivers and seepage as droplets on the cave ornaments. The component of this flow is laminar and its characterization can follow Darcy's law (White, 1993). Meanwhile, component dominates the conduit flow within underground river especially during the flood event and performs quick response to the rainfall, because it is directly recharged by surface flow into the karst aquifer via 
ponor and sinkhole. The nature of this component is turbulent flow and Darcy's law can not be applied (Jankowski, 2001).

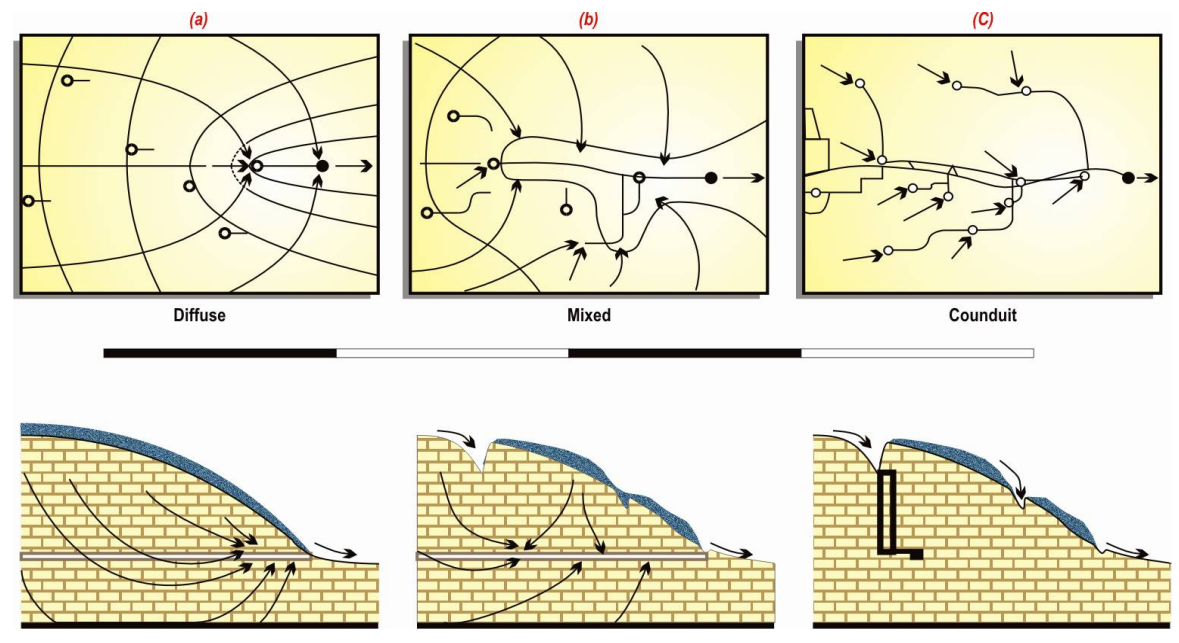

Gambar 2. Diffuse, mixed dan conduit aliran airtanah karst (Domenico and Schwartz, 1990)

Water stored in the karst hills gradually released both as Spring and underground rivers. Water travel down to the underground river system or Spring according to Gunn (1981) through which at least six mechanisms: surface runoff, trough flow, subcutaneous flow, shaft flow, vadose flow, and vadose seepage. The sixth flow will give a different response on the underground rivers and Spring. Underground rivers and Spring that are dominated by conduit flow will respond quickly surface flow and shaft flow, while perennial karst Spring generally is dominated by diffuse flow with a fairly long response (Linhua, 1996).

\section{FLOOD HYDROGRAPH RECESSION CONSTANT}

If within underground river we recognize three kinds of flow components as already described in the discussion above that is diffuse, fissure, and the conduit, then the flood hydrograph at the surface of any river flow has three main components which are identical to the 
baseflow that equivalent to a diffuse flow, the flow between (interflow-equivalent fissure flow), and surface flow (channel flow-equivalent conduit flow). This concept of which was introduced by Schulz (1976) who considered an aquifer as a water-storage media after flood events will gradually release the three components of the water savings as a function of time, as shown in Figure 3.

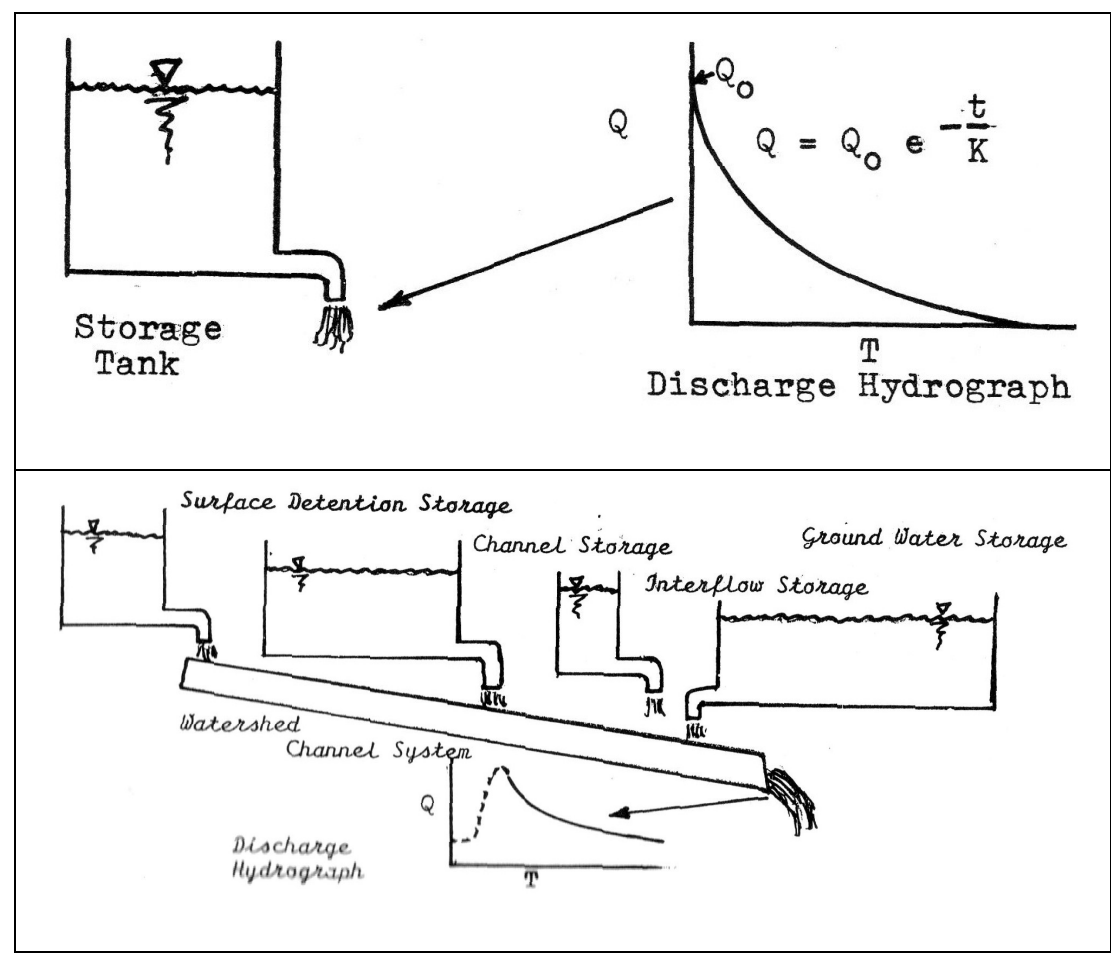

Figure 3. Releasing of water storage as a component of the aquifer flow (Schulz, 1976)

Recession curve (Figure 3-top) is division of a flood hydrograph (Figure 3-bottom) on an underground river after no rainfall to occur, so the discharge released goes down or releasing the flow components. Slope or the slope of the curve further away from the peak flood recession will be more evenly because the conduit flow has been released. Subsequently, diffuse flow becomes dominant. Curve of this recession period continues until the flood happens again. If we refer to Figure 3 , in the period of this recession curve was three times the release by each component of diffuse, fissure, and conduit flow, which, if then we call a recession segment certainly has a 
different slope as well. Recession segments can be selected from a flood hydrograph can be analyzed individually or together to gain an understanding of the flow components that influence the baseflow characteristics (Adji et al, 2009). Traditionally, the analysis is conducted with a graphical approach, but at this point is more likely to use a mathematical model. Each segment is often supposed recession as a decline exponentially, such as exists in physical phenomena such as heat flow, diffusion, or radioactive, which is formulated as follows:

$$
Q_{t}=Q_{0} e^{-\alpha t}
$$

where $\mathrm{Q}_{\mathrm{t}}$ is the flow rate at time $\mathrm{t}, \mathrm{Q}_{0}$ is the initial discharge in a recession segment, and $\alpha$ is a constant. Furthermore, $e^{-\alpha}$ in formula (1) can be replaced by $k$, which is known as a recession constant or depletion factor, which generally used as an indicator of the sustainability of the basic flow (Nathan and McMahon, 1990). From the result, they make range daily recession constant values varied from 0.2 to 0.8 for channel flow; 0.7 to 0.94 for intermediate flow, and from 0.93 to 0.995 for baseflow. The larger the value gained a recession, then the dominance of the baseflow to the underground river is getting bigger.

\section{SITE SELECTION AND RECESSION CONSTANTS APPLICATION}

One of groundwater storage prospective is aquifer within karst region. Regional hydrologic system was originally formed by dissolution process or often referred to as karstification. The first hydrological research conducted in the Gunung Sewu karst area is done by Mac Donald and Partners (1984) who later managed an inventory of water resources and also conducts an analysis of existing water quality and track the underground river system in a method to map caves found field and then took samples of water in the cave and also apply water tracing 
techniques in the caves to find the underground river system. The results obtained with the inventory of the cave approximately as much as \pm 230 and there are at least 40 caves with water resource potential. Three locations that become the object of this research are: Beton Spring represents the high elevation of research area, then Toto Cave-underground river (middle elevation), and Seropan Cave as representation of low elevation, which its water is managed by the taps to be used by residents (Samodra, 2005).

In fact, until this study focuses on hydrological behavior at underground river in a timeseries basis is still limited and the Spring are not yet available. Research is often conducted only in a single moment measurement so it can not be used to characterize of the aquifer comportment (Adji, 2010). Furthermore, the main purpose of this study is to calculate the discharge recession constant in several caves and spring that can differentiate the nature of the karst aquifer in releasing their storage on the basis of discharge records for several months (Adji, 2010). Then, from the flood hydrograph of data recorded, will be known the nature of the response parameters of rain on karst aquifer in Seropan and Toto underground river as well as Beton Spring. In addition, the recession constant value will be needed in calculating the percentage of baseflow from an aquifer automatically on a long-time recording (Eckhardt, 2005). Thus, knowledge of the constant baseflow recession and the amount will be used to monitor the sustainability of karst storage media, especially in the area of karst water catchments Seropan and Toto underground river and Beton Spring in the future.

\section{RESEARCH METHOD}

\section{Distribution of gauge}


Very existence of many caves and Spring in the karst area of Gunung Sewu, but not all water level relationships and time recording devices may be installed, but must be selected on the basis of distribution and access to get into the caves and Spring. Furthermore, a few aspects to consider in determining the position of measurement tools include the following:

(a) Whether there is an underground river and Spring.

(b) Ease of accessibility

(c) On the underground River appliance installed in the river segments that have a relatively straight section and at the Spring in place of existing installed equipment water flow.

\section{Equipment used}

Some equipments used in this study were:

a) Flow Meter (Current meters). Discharge measurements carried out several times when the stage of discharge in small, average, or immense condition, and subsequently to construct stage discharge rating curve in order to obtain variation of monthly discharge.

b) Water level recording devices (water level data logger). To determine the fluctuation of water level every 30 minutes in a time series, flow station installation required the installation of recording devices at the same time the water level in the form of automatic water level data logger. 
Citation :Indonesian Journal of Geography 2010, XLII(1)

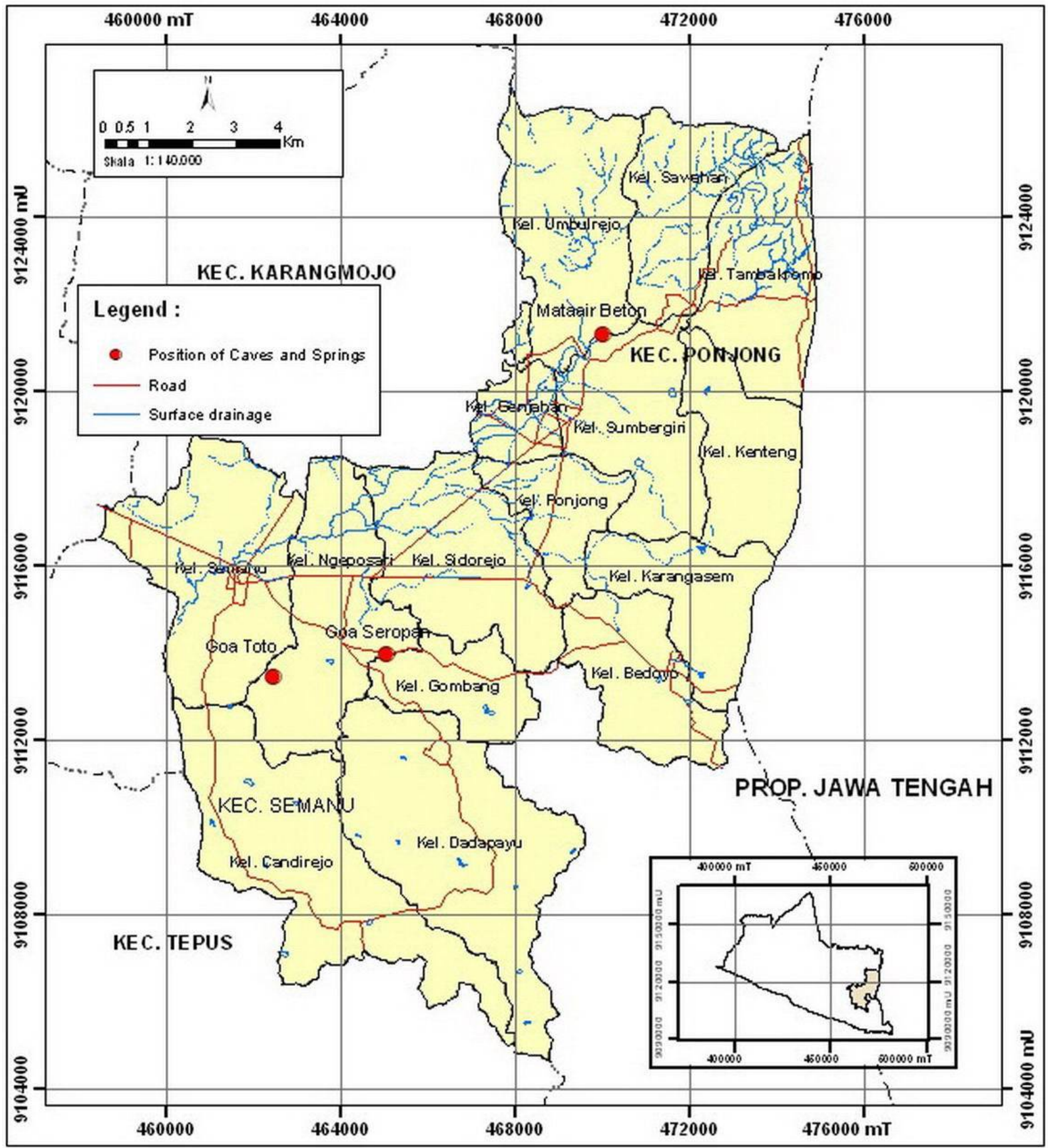

Figure 4. Plotting of Observed Caves and Spring 


\section{Discharge measurement}

After recording devices attached to water level fluctuations, in certain periods of discharge measurements for obtaining stage-discharge rating of the curve of Seropanunderground river, and Beton Spring so that the time-series for a several months of discharge can be obtained on the basis of water level fluctuations. Illustration of measurement of discharge using the area velocity method with the help of tools on current meter attached to the caves of water level recording devices.

\section{Selection and calculation of flood recession constant}

In Seropan and Toto underground river, as well as within Beton Spring, floods happened dozens of times in a period of one rainy season. However, analysis was not performed on every flood events. Selection is based on the flooding that analyzed the representation of the value of the required time of peak flood flow ( $t_{b}=$ time to base flow), with the intention that the floods are very small or very short can be ignored since it is not mathematically valid if measured at recession constant imposed (Schulz, 1976). Furthermore, the constant flood recession was elected in the various components of the flow sought by the equation:

$Q(t)=Q\left(t_{o}\right) e^{-k\left(t-t_{o}\right)}$

where, $\mathrm{k}$ is a recession constant in an aquifer system, $\mathrm{t}$ is the time to discharge in $\mathrm{t}$, and $\mathrm{t}_{0}$ is the time in the early discharge of a recession period. Thus within semi-log scale, the formula is considered to be linear, then:

$$
\begin{aligned}
& \ln Q(t)=-k\left(t-t_{o}\right)+\ln Q\left(t_{o}\right) \\
& k=-1 / t-t_{o} \ln \left(Q_{t} / Q_{o}\right)
\end{aligned}
$$




\section{RESULTS AND DISCUSSION}

Measurement of discharge on the location of water level recording devices during the year carried out at certain moments that represent different water level conditions. Discharge measurements conducted as much as seven times in Seropan Cave, nine times in Toto Cave, and 17 times in Beton Spring, which detailed results shown in Table 1.

Furthermore, regression analysis conducted to obtain the stage discharge rating curve. By this formula, the discharge estimation can be done simply by looking at water level on the measuring ruler is attached near the water level recording devices. Next, rating curve after regression analysis produced the formula:

- Beton Spring, $\quad y=4449,6 x^{2,332}$

- Seropan Cave, $\quad y=1418,9 \operatorname{Ln}(x)+557,22$

- Toto Cave, $\quad y=5500,3 x^{2}-3007,9 x+536,37$

where, $y$ is the discharge $(1 t / s e c)$ and $x$ is the height of water surface (m)

Then, the formula used to calculate the discharge in several month recording (Beton Spring-9 months, Seropan Cave 7 months, and Toto Cave-11 months) with a time interval of recording the water level every 30 minutes.

Number of flood events that occurred in the Beton Spring, Seropan Cave, and Toto Cave of Toto is $23,7,7$ flood events, respectively. Calculation of the recession in the flow of each component performed after the assortment of the floods are eligible, i.e. flood with sufficient discharge to be analyzed and which represent different variations of time to baseflow $\left(T_{b}\right)$, that is flood with its discharge performs the time between flood peak until the time of loss or expiration 
Citation :Indonesian Journal of Geography 2010, XLII(1)

component flow conduit and fissure, and left only a diffuse flow component. Then, the calculation of recession constant value, time to flood and the time to baseflow in the Beton Spring, Seropan Cave, and Toto cave is summarized Table 2.

Table 1. Measurement of discharge at different water level conditions

\begin{tabular}{|c|c|c|c|c|c|c|c|c|}
\hline \multicolumn{3}{|c|}{ Beton Spring } & \multicolumn{3}{|c|}{ Seropan Cave } & \multicolumn{3}{|c|}{ Toto cave } \\
\hline Date & $\begin{array}{c}\text { Water } \\
\text { level }(\mathrm{m})\end{array}$ & $\begin{array}{c}\text { Discharge } \\
(1 \mathrm{lt} / \mathrm{sec})\end{array}$ & Date & $\begin{array}{c}\text { Water } \\
\text { level }(\mathrm{m})\end{array}$ & $\begin{array}{l}\text { Discharge } \\
(1 t / \mathrm{sec})\end{array}$ & Date & $\begin{array}{c}\text { Water } \\
\text { level }(\mathrm{m})\end{array}$ & $\begin{array}{c}\text { Discharge } \\
(\mathrm{lt} / \mathrm{sec})\end{array}$ \\
\hline $11 / 13 / 07$ & 0.25 & 100.01 & $24 / 01 / 09$ & 1190 & 810 & $11 / 01 / 08$ & 0.294 & 129 \\
\hline 05/01/08 & 1.00 & 4426.80 & 02/02/09 & 1210 & 825 & $25 / 11 / 08$ & 0.500 & 409 \\
\hline $12 / 01 / 08$ & 0.65 & 1437.20 & $02 / 26 / 09$ & 1250 & 880 & $24 / 01 / 09$ & 0.274 & 110 \\
\hline $01 / 19 / 08$ & 0.54 & 860.89 & $04 / 21 / 09$ & 1269 & 890 & $02 / 26 / 09$ & 0.312 & 143 \\
\hline $26 / 01 / 08$ & 0.40 & 686.89 & $05 / 26 / 09$ & 1270 & 890 & $04 / 21 / 09$ & 0.344 & 148 \\
\hline $09 / 2 / 08$ & 0.62 & 1392.31 & $30 / 05 / 09$ & 1254 & 870 & $05 / 26 / 09$ & 0.358 & 153 \\
\hline $16 / 02 / 08$ & 0.67 & 1808.56 & $20 / 06 / 09$ & 1300 & 940 & $20 / 06 / 09$ & 0.339 & 147 \\
\hline $23 / 02 / 08$ & 0.70 & 2069.86 & & & & 07/09/09 & 0.320 & 131 \\
\hline $01 / 3 / 08$ & 0.59 & 1133.49 & & & & 05/08/09 & 0.310 & 159 \\
\hline $08 / 3 / 08$ & 0.64 & 1688.71 & & & & & & \\
\hline $03 / 15 / 08$ & 1.08 & 5550.56 & & & & & & \\
\hline $03 / 29 / 08$ & 0.60 & 1533.83 & & & & & & \\
\hline $04 / 12 / 08$ & 0.63 & 1260.23 & & & & & & \\
\hline $05 / 10 / 08$ & 0.39 & 412.28 & & & & & & \\
\hline $28 / 07 / 08$ & 0.27 & 204.97 & & & & & & \\
\hline $08 / 31 / 08$ & 0.22 & 178.88 & & & & & & \\
\hline $20 / 09 / 08$ & 0.24 & 136.71 & & & & & & \\
\hline
\end{tabular}

Source: Field measurement year 2008-2009

Table 2. Summary of recession constant values and flood parameters of Beton Spring, Seropan Cave, and Toto Cave

\begin{tabular}{|c|c|c|c|c|c|}
\hline Location & $\mathbf{K}_{\mathbf{c}}$ & $\mathbf{K}_{\mathbf{i}}$ & $\mathbf{K}_{\mathbf{b}}$ & $\mathbf{T}_{\mathrm{p}}$ (hours) & $\mathbf{T}_{\mathbf{b}}$ (hours) \\
\hline Beton Spring & $\begin{array}{l}0.135 \text { to } .989 \\
(\operatorname{avg}=0.720)\end{array}$ & $\begin{array}{l}0.879 \text { to } 0.997 \\
(\operatorname{avg}=0.950)\end{array}$ & $\begin{array}{l}\text { From } 0.938 \text { to } 0.999 \\
\quad(\text { avg }=0.983)\end{array}$ & $\begin{array}{c}0.5 \text { to } 41.5 \\
(\operatorname{avg}=12.87)\end{array}$ & $\begin{array}{c}12-1344 \\
(\operatorname{avg}=193.43)\end{array}$ \\
\hline Seropan Cave & $\begin{array}{c}0.256 \\
(\operatorname{avg}=0.258)\end{array}$ & $\begin{array}{c}0.709 \text { to } 0.956 \\
(\operatorname{avg}=0.703)\end{array}$ & $\begin{array}{l}\text { From } 0.992 \text { to } 0.9991 \\
\quad(A v g=0.996)\end{array}$ & $\begin{array}{c}2-327.5 \\
(\operatorname{avg}=83.64)\end{array}$ & $\begin{array}{c}7.5 \text { to } 3528 \\
(\mathrm{avg}=619.21)\end{array}$ \\
\hline Cave Toto & $\begin{array}{l}0.737 \text { To } .769 \\
(\operatorname{avg}=0.753)\end{array}$ & $\begin{array}{c}0.648 \text { to } 0.956 \\
(\operatorname{avg}=0.802)\end{array}$ & $\begin{array}{c}0.860 \text { to } 0.988 \\
(\mathrm{avg}=0.937)\end{array}$ & $\begin{array}{c}5 \text { to } 32.5 \\
(\operatorname{avg}=14.43)\end{array}$ & $\begin{array}{c}66-3696 \\
(\operatorname{avg}=910)\end{array}$ \\
\hline
\end{tabular}

$* \mathrm{~K}_{\mathrm{c}}=$ conduit recession constant; $\mathrm{K}_{\mathrm{i}}=$ fissure recession constant; $\mathrm{K}_{\mathrm{b}}=$ diffuse recession constant ; avg = average $\mathrm{T}_{\mathrm{p}}=$ time to peak $; \mathrm{T}_{\mathrm{b}}=$ time to baseflow 
From the data summary presented in Table 2, it gives the impression that the variation of the recession constant value for the diffuse flow component, fissure, and conduit in Beton Spring, Seropan Cave, and Toto Cave is very high. Average value of diffuse flow recession constants highest found in Seropan Cave (0.996) with a small variation of $\mathrm{K}_{\mathrm{b}}$ values indicate that the dominance of diffuse flow on the scale of post-flood period still performs fine condition within short and long term of recession period. This proved by Cave Seropan that never dry on top of the dry season with minimum discharge measured was above $810 \mathrm{lt} / \mathrm{sec}$.

Meanwhile, Toto Cave performs the smallest recession constant of diffuse flow, with a variation of values along the flood period is immense enough (from 0.860 to 0.988 ). This condition affects the behaviour of flooding in the Toto Cave is fast enough $\left(\mathrm{T}_{\mathrm{p}}=4.43\right.$ hours $)$, which then discharge flows down to reach baseflow conditions ( $T_{b}=910$ hours), if compared to the value found in Beton Spring and Seropan Cave. Because the value of $K_{b}$ are smaller than the Beton Spring and Seropan Cave, Toto Cave has a minimum discharge, which is smaller than the other two places, reaching just 110 lt/sec on January 24, 2009. Next, Beton Spring that located at the highest elevation of research area, have the nature to release its aquifer diffuse component in medium value (0.938 to 0.999$)$, if compared to the two other places, but they have the greatest measurable discharge of 5550.56 lt/sec. In addition, Beton Spring performs the fastest time to base flow $\left(\mathrm{T}_{\mathrm{b}}\right)$ value (193.43 hours).

Furthermore, the recession constant value for the conduit flow $\left(\mathrm{K}_{\mathrm{c}}\right)$ showed that the Beton Spring and Seropan Cave has a steep recession (from 0.135 to 0.989) and (0.258) with an average value during flood periods of 0,720) for Beton Spring and 0.258) for Seropan Cave. According to Schulz (1976), the value of small recession constant for channels flow has the characteristics of flooding more quickly than if its value is greater in $\mathrm{K}_{\mathrm{c}}$. In this case, Beton Spring has an average 
value of $\mathrm{K}_{\mathrm{c}}$ is smaller (0.720) when compared with the value in Toto Cave because the domination of conduit flow, which has a rapid response to the flood peak, while the value of $\mathrm{T}_{\mathrm{b}}$ performs the most rapid value when compared to other two places. Meanwhile, recession constant value or fissure $(\mathrm{Ki})$ at three sites presents a different value. Beton Spring have average value of $\left(\mathrm{K}_{\mathrm{i}}\right)$ is the highest $(0.950)$ was followed sequentially by Toto and Seropan Cave (0.802 and 0.703). This $K_{i}$ value indicates the fissure pattern (mid-sized cracks) on the existing aquifer in the study area. Value of $\mathrm{K}_{\mathrm{i}}$ within Beton Spring gives the sense that medium-fissure cavities in the aquifer has not been much developing toward the conduit cavities, unlike the case with those of Toto and Seropan Caves that have value (Ki) is smaller meaning that the secondary cracks in both places are more developed when compared to those in Spring Beton evidenced by the response to flooding quickly so the time needed to reach flood peak $\left(T_{p}\right)$ quickly, given the second place position in the low elevation part.

By looking at the values related to the recession constant of aquifer flow to release its components in different components, it appears that Beton Spring representing the high elevation study area has the most rapid response to rain events, and has average value of $\mathrm{K}_{\mathrm{b}}$ is lower than the Seropan Cave, meaning that the ability to store water infiltration on karst surface is slightly lower than the surface conditions in the lower elevation, represented by Seropan Cave, although the range of numbers of $K_{b}$ in Beton Spring is still considered very good (>0.9). In addition, the discharge channel in Beton Spring have a fast response (compared to Seropan and Toto Caves) to the occurrence of rain events within its catchment area $\left(T_{p}=12\right.$ hours). From this value, likely contributing factor is the distance between catchment area and the point of Beton Spring, or surface conditions in the upstream region which has many sinkhole. This is different to that seen in the value of $\mathrm{K}_{\mathrm{b}}$ at the Toto Cave, which, though smaller than that calculated in Beton Spring, 
but because it is situated more toward the lower elevation, it has a value of $\mathrm{T}_{\mathrm{b}}$ is longer than the Spring Beton (910 hours—-see Table 2). Meanwhile, Seropan Cave still has more dominance in the provision of diffuse flow component (when classified by $\mathrm{K}_{\mathrm{b}}$ value), compared to Beton Spring and Toto Cave.

\section{REFERENCES}

Adji, T.N., 2005, Agresivitas Airtanah Karst Sungai Bawah Tanah Bribin, Gunung Sewu, Indonesian Cave and Karst Journal, Vol. 1 No1, HIKESPI

Adji, T.N., 2010. Variasi Spasial-Temporal Hidrogeokimia dan Sifat Aliran Untuk Karakterisasi Sistem Karst Dinamis di Sungai Bawah Tanah Bribin, Kabupaten Gunung Kidul, DIY, Disertasi, Fakultas Geografi, Universitas Gadjah Mada, Yogyakarta

Adji, T. N., 2010. Spatial and Temporal Variation of Hydrogeochemistry and Karst Flow Properties to Characterize Karst Dynamic System in Bribin Underground River, Gunung Kidul Regency, DIY Province Java, Indonesia. Summary, Dissertation in Geography Study Program. Graduate School of Geography, Gadjah Mada University, Yogyakarta

Adji, T.N., Hendrayana, H., Sudarmadji, E., Woro, S, 2009, Diffuse Flow Separation Within Karst Underground River at Ngreneng Cave, Proceeding of International Conference Earth Science and Technology, 6-7 Aug 2009, Yogyakarta

Anthony, D.M., Groves, C., Meiman, J., 1997. Preliminary investigations of seasonal changes in the geochemical evolution of Logdson River, Mammoth Cave, Kentucky, Proceedings of the 4th Mammoth Cave Science Conf., Mammoth Cave, KY, 15-23.

Blair, R.W., 2004, Karst Landforms and Lakes, Geomorphology from Space, NASA, USA

Dane, F.C. 1990. Research Methods, Brooks/Cole Publishing Company, Pacific Grove, California

Domenico,P.A. and Schwartz, F.W., 1990, Physical and Chemical Hydrogeology. $2^{\text {nd }}$ Ed. John Wiley \& Sons

Etfimi, R., 2005. Use of hydrochemical studies to identify the recharge sources of karst Spring; example of Poceme Spring in Albania, Geophysical Research Abstracts, Vol.7, 04063

Ford, D. and Williams, P. 1992. Karst Geomorphology and Hydrology, Chapman and Hall, London

Gillieson, D., 1996, Caves: Processes, , Oxford

Gunn, J., 1981. Hydrological processes in Development, and Management, Blackwell karst depression, $Z$. Geomorph. N.F, (25)3,313-331

Haryono, E., 2001. Nilai Hidrologis Bukit Karst, Makalah pada seminar Nasional, Eko-Hidrolik, 28-29 Maret 2001, Jurusan Teknik Sipil , UGM

Haryono, E. dan Adji, T.N. 2004. Geomorfologi dan Hidrologi Karst. Yogyakarta: Kelompok Studi Karst, Fakultas Geografi, Universitas Gadjah Mada

Jankowski, J., 2001. Groundwater Environment, Short Course Note, School of Geology, University Of New South Wales, Sydney, Australia

Karimi, H., Raeisi , E., Zare, M. 2003. Hydrodynamic behavior of the Gilan karst spring, west of Zagros, Iran. BCRA Cave and Karst Science. Vol 30 (1) pp 15 - 22 
Citation :Indonesian Journal of Geography 2010, XLII(1)

Liu, Z.,Groves,C., Yuan,D., Meiman,J., 2004(a). South China Karst Aquifer Storm-Scale Hydrochemistry, Ground Water. 42, Jul/Agt 2004

Liu, Z.,Groves,C., Yuan,D., Meiman,J., Jiang, D., He, S., Li,Q., 2004(b). Hydrochemical variation during flood pulses in the south-west peak cluster karst : impacts of $\mathrm{CaCO}_{3}-\mathrm{H}_{2} \mathrm{O}-\mathrm{CO}_{2}$ interactions, Hydrological Processess. 18, 2423-2437

Linhua S., 1996. Mechanism of Karst Depression Evolution and Hydrological Evolution, ActaGeographica Sinica, 41 41-50.

MacDonalds and Partners. 1984. Greater Yogyakarta - Groundwater Resources Study. Vol 3C: Cave Survey. Yogyakarta, Directorate General of Water Resources Development Project (P2AT)

Nathan R.J., McMahon T.A., 1990. Evaluation of automated techniques for baseflow and recession analysis. Water Resources Research. 26(7):1465-1473.

Raeisi, R., Karami, G., 1997. Hydrochemographs of Berghan karst spring as indicators of aquifer characteristics, Journal of Cave and Karst Studies 59(3), 112-118

Samodra, H., 2005. Monografi Karst Gunung Sewu, Pusat Penelitian dan Pengembangan Geologi, Badan Geologi, Departemen Energi dan Sumberdaya Mineral.

Schulz, E.F., 1976. Problems in Applied Hydrology. Water Resources Publication, Colorado

Smart, P.L. and Hobbes, S.L., 1986. Characteristics of Carbonate Aquifers: A conceptual basis. In Proceedings, Environmental Problem in Karst Terrains and Their Solution. Bowling Green, KY: National Well Water Association, 1-4

White, W.B., 1988. Geomorphology and Hydrology of Karst Terrain. Oxford University Press, New York

White, W.B., 1993. Analysis of Karst Aquifer. In:Alley, W.M. (editor), regional groundwater Quality. Van Nostrand Reinhold, New York 